\title{
Migrant home care workers caring for older people: fictive kin, substitute, and complementary family caregivers in an ethnically diverse environment
}

\author{
By Andreas Hoff ${ }^{1}$, Susan Feldman ${ }^{2} \mathcal{E}$ Lucie Vidovicova ${ }^{3}$
}

The world's population is ageing, both in the more developed and the less developed regions. Contrary to popular belief, the majority of older people live in less developed countries such as China or India due to the sheer numbers of their populations. More developed societies also have large numbers of older people in their populations relative to that of younger people due to low fertility rates and increasing longevity. Currently, the oldest society in the world is Japan, where $22.7 \%$ of the population are 65 years and older, followed by Germany $(20.4 \%)$ and Italy $(20.1 \%)$, proportions that will increase to almost a third in Japan and more than a quarter in Germany, Italy, Finland, and Slovenia by 2030 (International Institute for Applied System Analysis [IIASA] 2010). A characteristic feature of this population ageing is the accelerated ageing of the "oldest old" i.e. those aged 80 years and older (Eurostat 2010; United Nations [UN] 2010). This is of particular relevance in the context of this Special Issue on Migrant Care Workers Caring for Older People in their Homes,

\footnotetext{
${ }^{1}$ Andreas Hoff, Oxford Institute of Ageing, University of Oxford, UK and Zittau/Görlitz University of Applied Sciences, Görlitz, Germany

${ }^{2}$ Susan Feldman, Healthy Ageing Research Unit, Faculty of Medicine, Nursing and Health Sciences, Monash University, Australia

${ }^{3}$ Lucie Vidovicova, Faculty of Social Studies, Masaryk University, Czech Republic
} 
International Journal of Ageing and Later Life

since people in their 80 s are at a much higher risk of needing care than those in their $60 \mathrm{~s}$ and $70 \mathrm{~s}$ and, thus, represent the majority of care recipients assisted by migrant care workers.

Traditionally, caregiving has been delivered informally by members of an older person's family. However, the combined effects of a shrinking pool of young and middle-aged potential caregivers, increasing labour market pressures, and the extension of working lives - in many cases to supplement public pensions - are making this increasingly difficult. In principle, there are two contrasting solutions to the dilemma of growing demand for care at times of depleting supply by assigning ultimate responsibility for caregiving to two different societal actors: The first solution would be to frame care provision as a societal task rather than a private matter. Accordingly, responsibility for care provision would then lie with the welfare state and funded through general taxation and social insurance contributions. Comprehensive care provision through public care providers, both in institutional and in social care, would be the norm. Families who still have to - or prefer to - provide care would be recompensated for doing so by the state. This solution is sometimes referred to as "high road solution" (Leeson \& Hoff 2009).

In contrast, the "low road solution" aims at saving public expenditure by assuming the continuation of traditional caregiving roles by the family (women), thus assigning families the ultimate responsibility for care provision. However, the latter approach is no longer compatible with the "double earner" reality of working lives as experienced by most men and women in contemporary societies, which inevitably results in the search for solutions that fall "in-between" the above-mentioned "high road/low road" poles. The employment of migrant care workers in older people's homes is an example of such an "in-between" solution, often resorted to by desperate families caught between caring responsibility and the need to earn a living. It is thus an unintended side-effect of public policies promoting the traditional family caregiving model that leaves responsibility for the organisation and provision of care with the family, which - despite slightly increasing numbers of men providing care - effectively still translates into female caring responsibility, ignoring the fact that the context in which contemporary families operate has changed. 
The matter is further complicated by the persistence of traditional caregiving norms and values embedded in contemporary societies' cultural heritage. As a consequence, family care provision is often expected and the preferred arrangement in most European countries. Various studies have confirmed this, such as the European DIALOG project, in which 14 different European countries participated (Höhn et al. 2008). When asked about help from private persons (which may include migrant care workers), $40 \%-60 \%$ would prefer that, with the highest figure in Austria $(77 \%)$ and the lowest in Finland (39\%) (Höhn et al. 2008). These expectations may result in additional tensions when facing the realities of giving care.

In the European context, "high road solutions" to delivering care in an ageing society would be exemplified by the Scandinavian or Nordic care regime (Denmark, Finland, Norway, or Sweden), which is characterised by predominance of public care services, while the Mediterranean or Southern European countries (Cyprus, Greece, Italy, Malta, Portugal, or Spain) would represent the other extreme, with almost exclusively family care provision (Anttonen \& Sipilä 1996). Anttonen and Sipilä did not make any reference to the post-communist societies of Eastern Europe that in our view would be another example for almost total reliance on family care resources, with hardly any public care provision available. The remaining European countries would sit somewhere in-between, with varying degrees of family and state responsibility for care provision - as would Austria, Canada, and Israel, the "migrant care worker receiving" countries covered in this Special Issue.

Most of what has been said above was in reference to the "demand side" of the migrant home care worker debate, i.e. the perspective of families with caregiving responsibility for an older person. However, there is also a "supply side" to the migrant care worker phenomenon. The economic impact of globalisation has seen a growth of migration flows to Western societies, with migrants quickly responding to socio-economic needs in the West while trying to escape socio-economic hardship in their countries of origin in the less developed world. The "surge in female-driven immigration" (Leeson \& Hoff 2009: 1) in response to increasing demand for both formal and informal eldercare labour is a good example. This has also resulted in subtle changes in the gendered experience of migration: while in the past migration was typically associated with young male 
International Journal of Ageing and Later Life

workers, increasing numbers of contemporary migrants are female (Arya \& Roy 2006; George 2005), with many of them working in eldercare (Leeson \& Harper 2006).

Global movements of labour have implications for both the migrant care worker "receiving" and for the migrant care worker "sending" societies. While the former countries benefit from the care labour provided by migrant care workers, the latter may benefit from remittances these migrant workers send home, as is evident in a large body of research literature on remittances (see, for example, Goldring 2004; Rapoport \& Docquier 2006; Russell 1986).

Less well documented are the consequences for migrant care workers' families who are left behind in their home countries. Implications for the families of people who leave to work as carers in other countries range from the need to reorganise their own family care arrangements to possible conflict between legal and moral obligations. The impact of migration on the wider family network also needs to be taken into consideration. Some writers have reported the establishment of other informal support structures (e.g. grandparents, other relatives) to fill the arising gaps in child care and care for older family members (Leeson \& Hoff 2009).

The "migrant sending" versus "receiving" dichotomy also implicitly points to the very dynamic nature of migration processes. Migration flows are far from static - they respond quickly to changing socio-economic circumstances, as the example of a rapidly decreasing inflow of Eastern European immigrants to the UK in response to the 2008 economic crisis demonstrates (BBC 2009). Moreover, several of today's main migrant receiving countries were migrant sending countries not too long ago - see the examples of Italy, Spain, or Ireland. Today, the transition from a migrant sending to a migrant receiving country occurs at an even more rapid pace, sometimes even within the space of a few years. In some cases, this rapid transformation process even results into a situation where societies simultaneously experience the process of both migrant sending and migrant receiving, as the example of Poland shows. Polish migrant care workers are known to be working across Europe (in Germany, Ireland, Italy, Sweden, or the UK, for example). What is less well known is that Poland (at least the metropolitan area around the capital Warsaw) has 
also experienced an influx of migrant care workers from Belarus and the Ukraine (Fratczak 2007).

This type of migration, i.e. the replacement of lost labour through immigration from even poorer countries, however, does not represent a sustainable solution to the problem. Welfare gap theory can be used to explain economic migration from one country to another (see Vobruba 1998, 2003). According to this theory, people from a less well off society (e.g. Poland) migrate to another country where they can earn higher wages (e.g. the UK) relative to their country of origin. That country of origin (Poland), however, may offer better economic prospects to workers from an even more deprived society (the Ukraine, for example). It would however be short-sighted to assume that there will always be a poorer country that would solve the problems of a wealthier one. Assuming that there will be a continuous supply of migrant labour from a particular migrant sending country to replace or supplement family care in a specific migrant receiving country is likely to be fallible in the long-term since it does not take into account future socio-economic changes in both sending and receiving societies, which may change the incentive structure for migration as well as for trying to attract migrants.

Moreover, questions might be raised about ethics for countries striving to solve their problems at the expense of others, as the "brain drain" discourse in regard to attracting the educated elites from developing countries to come and stay in the Western world pointed out. In this debate it was proposed that such a position deprived the home societies of human capital (i.e. a very scarce resource). Likewise, employing care workers from developing countries in Western societies to fill labour shortages in aged care results in a "care drain" in the sending countries (Leeson \& Hoff 2009).

But ethical considerations also apply to the relationship between migrant care worker and indigenous care recipients, which is often characterised by multiple dependencies. Many migrant home care workers actually live in the care recipient's home, which enables them to provide care up to 24 hours a day, seven days a week. Obviously, these working hours would not be tolerated in the formal labour market. Moreover, migrant care workers employed by families on an informal basis are in many, if not in most cases, not appropriately compensated for the long 
International Journal of Ageing and Later Life

hours they work. Additionally, live-in carers depend on the care recipients (and their families) for their accommodation, a dependency that is further emphasised in the case of foreign workers who entered the host society illegally (Leeson \& Hoff 2009).

On the other hand, the care recipient is also dependent on the care worker for providing care, which makes him or her a potential target of physical or mental abuse. In addition, the quality of care provided by an often untrained, unqualified care worker is an issue. Another concern in increasingly culturally diverse societies is that of "culture-sensitive" care. Whereas this concept has so far mainly been applied to older people from ethnic minority backgrounds receiving care, the employment of a migrant care worker (from Latin America, Africa, or Asia) foreign to the host society and who does not necessarily speak the language of the native population for whom they provide care, let alone understand their cultural needs, is problematic (Leeson \& Hoff 2009).

Although there is an abundance of anecdotal and mass media evidence of the increasingly important role migrant care workers play in enabling Western health and social care systems, as well as families coping with the demands of growing numbers of older people needing care, research-based literature is still scarce. Migration statistics are notoriously sketchy, particularly concerning repeated short-term or pendulum migration, as it is the case with migrant care workers, which does not really help the situation. Neither does the fact that illegal employment of a migrant care worker by families trying to avoid legally binding, but expensive social insurance payments in some countries (Germany, for example), makes this a criminal offence.

A few pioneering studies have been published in recent years providing invaluable insights into the increasingly important role played by migrant care workers in delivering family care. Unsurprisingly, most of these studies originate in familialistic societies, such as those clustered around the Mediterranean Sea in Southern Europe. Thereby, Italian researchers are leading the way (see, for example, Bettio et al. 2006; Bettio \& Plantenga 2004; Lamura 2007; Lamura et al. 2008). More recently still, first research evidence of the use of the same coping strategies by families further north in Europe was provided - for Ireland (Doyle \& Timonen 2009; Timonen \& Doyle 2010), the UK (Cangiano et al. 2009), and Germany (Hillmann 2005; 
Theobald 2010). Nevertheless, despite the recently growing popularity of migrant care workers as a research theme, the present Special Issue is still an important step filling a substantial gap in the research-based literature.

This Special Issue takes up the challenge and includes three papers by prominent writers in the field. First is a conceptual paper by Bernhard Weicht, focusing on Austria and the UK. Following a substantial review of existing literature on the migrant care worker problematic, his article focuses on the relation between the moral construction of migrant carers in the family-oriented welfare system of Austria and the ideological understanding of "ideal" care in society. Using Critical Discourse Analysis, the public discussion in newspapers is analysed, which is complemented through focus group interviews. Weicht suggests that migrant carers are constructed as fictive kin in public discourse in Austria, representing an approximation of the idealised family carer.

The following article by Esther Iecovich focuses on the specific situation of migrant live-in homecare workers, based on the case of Israel. The purposes of her study are to examine to what extent migrant live-in homecare workers substitute family caregivers or complement care provided by primary caregivers, and to examine how the employment of a migrant care worker changed the primary caregivers' involvement in providing help with Activities of Daily Living (ADL)/Instrumental Activities of Daily Living (IADL). Her research is based on a study of 335 triads (care recipients, their primary caregivers, and their Filipina live-in homecare workers).

The third paper is written by Anne Martin-Matthews, Joanie Sims-Gould, and John Naslund and extends the perspective to Canada, thereby focusing on the implications of caregiving by migrant care workers in an ethnically diverse social setting. Their paper investigates characteristics of immigrant homecare workers, and the ways in which they differ from non-migrant care workers in Canada. Their research is set in the ethnically very diverse metropolitan area of Vancouver, British Columbia, which has implications for the interaction between client and worker reflecting this ethno-cultural diversity, and the strategies employed by workers to address issues related to this diversity. Their study is based on interviews with 118 migrant care workers. 
International Journal of Ageing and Later Life

\section{Acknowledgements}

The editors would like to acknowledge the support received for preparing this Special Issue of IJAL from Research Committee 11 "Sociology of Aging" of the International Sociological Association (ISA). Furthermore, we would like to thank the participants in session S16 "Migrant Care Workers" of the Research Committee on Ageing (RC 11) conference programme at the First International Sociological Association's Forum of Sociology, held in Barcelona, Spain, on September 5-8, 2008.

Moreover, this editorial was in part inspired and informed by the NORFACE Seminar Series "Migrant Labour in the Eldercare Sectors" (MILES), coordinated by George W. Leeson and Andreas Hoff, Oxford Institute of Ageing, University of Oxford, in 2007 and 2008. Generous funding of the seminar series by NORFACE ERA-Net under the NORFACE Seminar Series 2006 "Immigration and Demographic Challenges in Europe" is gratefully acknowledged, as are the seminar series participants' contributions, which informed the final report of the seminar series (Leeson \& Hoff 2009), and thus indirectly the present editorial paper.

Finally, we would like to thank Laura Machat-From at IJAL for her very kind and highly efficient editorial support and the IJAL Editor in Chief Lars Andersson for his very helpful editorial guidance. Any omissions or mistakes are of course sole responsibility of the authors and guest editors of this Special Issue.

\section{References}

Anttonen, A. \& Sipilä, J. (1996). European social care services: Is it possible to identify models? Journal of European Social Policy 6(1): 87-100.

Arya, S. \& Roy, A. (eds.). (2006). Poverty, Gender and Migration. Thousand Oaks, CA: Sage.

BBC. (2009). More Eastern Europeans leaving UK. Available on http:// news.bbc.co.uk/1/hi/uk/8059122.stm (Accessed May 20, 2009).

Bettio, F. \& Plantenga, J. (2004). Comparing care regimes in Europe. Feminist Economics 10(1): 85-113. 
Bettio, F., Simonazzi, A. \& Villa, P. (2006). Change in care regimes and female migration: The "care drain" in the Mediterranean. Journal of European Social Policy 16(3): 271-285.

Cangiano, A., Shutes, I., Spencer, S. \& Leeson, G. W. (2009). Migrant Care Workers in Ageing Societies: Research Findings in the United Kingdom. Oxford: COMPAS.

Doyle, M. \& Timonen, V. (2009). The different faces of care work: Understanding the experiences of the multi-cultural care workforce. Ageing \& Society 29(3): 337-350.

Eurostat. (2010). Europe in Figures. Eurostat Yearbook 2010. Luxembourg: Publications Office of the European Union.

Fratczak, E. (2007). Poland as a migrant sending country. Paper presented at NORFACE "Migrant Labour in the Eldercare Sectors" Seminar in Oxford, January 8-10, 2007.

George, S. M. (2005). When Women Come First: Gender and Class in Transnational Migration. Berkeley: University of California Press.

Goldring, L. (2004). Family and collective remittances to Mexico. Development and Change 35(4): 799-840.

Hillmann, F. (2005). Migrants care work in private households, or the strength of bilocal and transnational ties as a last(ing) resource in global migration. In B. Pfau-Effinger \& B. Geißler (eds.), Care and Social Integration in European Societies (pp. 93-114). Bristol: Policy Press.

Höhn, C., Avramov, D. \& Kotowska, I. (eds.). (2008). People, Population Change and Policies. Lessons from the Population Policy Acceptance Study, Vol. 2: Demographic Knowledge, Gender, Ageing. Dordrecht: Springer.

International Institute for Applied System Analysis (IIASA). (2010). European demographic data sheet 2010. Available on http://www.iiasa. ac.at/docs/HOTP/2010/Jul10/DataSheet.pdf (Accessed: November 20, 2010).

Lamura, G. (2007). Italy's "familistic" approach to elderly care and the new role of migrant home care workers. In V. Burau, H. Theobald \& R. H. Blank (eds.), Governing Home Care. A Cross-National Comparison (pp. 118-121). Cheltenham: Edward Elgar.

Lamura, G., Melchiorre, M. G., Principi, A., Luccetti, M. \& Polverini, F. (2008). Migrant workers in the eldercare sector: The Italian experience. 
International Journal of Ageing and Later Life

In Securité Sociale t'Assurance Retraite Caisse Nationale (ed.), Retraite et Société Selection 2008 (pp. 125-152). Paris: CNAV.

Leeson, G. W. \& Harper, S. (2006). Foreign Workers in the Health and Social Care Sector in the United Kingdom. Tokyo: Japanese Council of Social Welfare.

Leeson, G. W. \& Hoff, A. (2009). Final Report of the NORFACE Seminar Series "Migrant Labour in the Eldercare Sectors." Oxford: Oxford Institute of Ageing.

Rapoport, H. \& Docquier, F. (2006). The economics of migrants' remittances. In S.-C. Kolm \& J. M. Ythier (eds.), Handbook of the Economics of Giving, Altruism and Reciprocity (pp. 1135-1198). Amsterdam: Elsevier.

Russell, S. S. (1986). Remittances from international migration: A review in perspective. World Development 14(6): 677-696.

Theobald, H. (2010). Migrant family carers in Austria and Germany: Policy fields, policy development and their interplay. Paper presented at the ESPAnet Conference, September 2-4, 2010, Budapest, Hungary.

Timonen, V. \& Doyle, M. (2010). Migrant care workers' relationships with care recipients, colleagues and employers. European Journal of Women's Studies 17(1): 25-41.

United Nations. (2010). United Nations programme on ageing. Available on http:/ / www.un.org/ageing/ popageing.html (Accessed: November 20, 2010).

Vobruba, G. (1998). The social dynamic of welfare gaps. Prolegomena to the transnationalization of sociology. Sociological Analysis 1(3): 27-40.

Vobruba, G. (2003). The enlargement crisis of the European Union: Limits of the dialectics of integration and expansion. Journal of European Social Policy 13(1): 35-49. 